15. Мирчинк Т.Г. Современные подходы к оценке биомассы и продуктивности грибов и бактерий в почве // Успехи микробиологии. 1985. Т. 20. С. 194-206.

16. Атлас Иркутской области: экологические условия. М.-Иркутск, 2004. 90 с.

17. Санитарные Правила и Нормы 2.1.7.573-96 «Гигиенические требования к использованию сточных вод и их осадков для орошения и удобрения» (2.1.7. Почва, очистка населенных мест, бытовые и промышленные отходы, санитарная охрана почвы). М. 1997. 36 с.
18. Практикум по микробиологии / Под ред. А.И. Нетрусова. М.: Издательский центр «Академия». 2005. $608 \mathrm{c}$.

19. Ананьева Н.Д. Микробиологические аспекты самоочищения и устойчивости почв. М.: Наука. 2003. $223 \mathrm{c}$.

20. Гузев В.С., Левин С.В. Перспективы экологомикробиологической экспертизы состояния почв при антропогенных воздействиях // Почвоведение, 1991, № 9. С. 50-62.

\title{
MICROBIOLOGICAL MONITORING OF ANTHROPOGENICALLY TRANSFORMED SOILS
} (C) 2016

\author{
E.V. Simonova, doctor of biological sciences, professor of the Chair of Microbiology, Virology and Immunology \\ Irkutsk State Medical University, Irkutsk (Russia) \\ E.N. Maksimova, candidate of biological sciences, associate professor of the Chair of Natural Sciences \\ Pedagogical Institute of Irkutsk State University, Irkutsk (Russia)
}

\begin{abstract}
The article presents results of microbiological monitoring of artificial soils. These soils were formed in the process of reclaiming technical lignin in special drives of the Baikal Pulp and Paper Mill (Irkutsk region). The test drives are in Solzanskom landfill, which is located between the vil. Solzan and the r. Bol'shaja Osinovka south of Irkutsk - UlanUde highway. Investigations were carried out in drives № 1, № 4, № 5, № 6. Soil samples were homogenized in a selected point on three levels. Evaluation of sludge lignin was conducted in accordance with generally accepted sanitary and microbiological methods of investigation of soils, using the integral index of general contamination of the soil. The research shows the role of aerobic and anaerobic microorganisms, bacteria and fungi in microbiocenosis. The degree of contamination of the soil is strong. The ratio of prokaryotic to eukaryotic microorganisms is $3: 1$ on the average. This suggests a significant role of bacterial forms in lignin biodegradation. The prevalence of the aerobic microorganisms over anaerobic ones shows that in the lower layers of sludge lignin biodegradation process is slow. The materials demonstrate that the methods of microbiological monitoring are proximate and provide a comprehensive assessment of the ecological status of the soil.

Keywords: sludge-lignin, total bacterial count, microbiocenosis, pollution degree, aerobic, anaerobic, prokaryotes, eukaryotes, bacteria, fungi, biodegradation, man-made pollutants, reclamation, microbial flora, sanitary and microbiological status, monitoring, pulp and paper mill.
\end{abstract}

УДК 581.524.344(470.54)

\section{ОСОБЕННОСТИ ТАКСОНОМИЧЕСКОЙ СТРУКТУРЫ ФЛОРЫ УРБАНИЗИРОВАННЫХ ТЕРРИТОРИЙ СРЕДНЕГО УРАЛА (СВЕРДЛОВСКАЯ ОБЛАСТЬ)}

(C) 2016

А.С. Третьякова, кандидат биологических наук, доцент кафедры ботаники

Уральский федеральный университет имени первого Президента России Б.Н. Ельцина, Екатеринбург (Россия)

Аннотация. Исследование урбанофлор крупное направление в ботанической науке. К настоящему времени достаточно подробно изучены флоры многих городов Российской Федерации. В то же время на Урале флора урбанизированных территорий практически не являлась предметом специальных исследований. В настоящей работе впервые дается развернутая характеристика особенностей таксономической структуры флоры урбанизированных территорий Среднего Урала в пределах Свердловской области и проводится сравнение ее параметров с региональной флорой Свердловской области. Изучены урбанофлоры 3 городов, расположенных в южной части Свердловской области - Екатеринбурга, Красноуфимска и Каменска-Уральского, которые образуют широтную катену, охватывающую Предуралье, горную часть Среднего Урала и Зауралье. Показано, что флору урбанизированных территорий отличает повышенный уровень видового богатства, который возрастает по мере увеличения площади города. В таксономической структуре урбанофлоры, в сравнении с региональной флорой, снижается участие споровых растений, за счет крайне бедной представленности плауновидных. Среди цветковых растений снижается доля однодольных и, наоборот, повышается - двудольных. Состав ведущих семейств урбанофлоры типичен для бореальных флор Голарктического флористического царства, в то же время его отличает понижение ранга семейства Cyperaceae и повышение - семейства Fabaceae. Родовой спектр урбанофлоры отличает повышенное участие в нем термофильных родов Atriplex и Chenopodium и крайне ограниченная представленность бореальных родов Hieracium и Тaraxacum. Видовая насыщенность семейств и родов в урбанофлоре заметно ниже, чем в региональных бореальных флорах.

Ключевые слова: урбанофлора, региональная флора, биологическое разнообразие, видовое богатство, таксономическая структура, семейственно-видовой спектр, видовая насыщенность семейства, родовой спектр, видовая насыщенность рода, Средний Урал, Свердловская область 
Урбанизация является доминирующей тенденцией развития общества в XX-XXI вв.: если до 1900 г. в городах проживало около $14 \%$ населения земного шара, то в конце XX века - около $45 \%$, а к 2025 г. в них будет проживать примерно $60 \%$ населения Земли $[1,2]$. С ростом городского населения увеличиваются и занимаемые городами площади - в настоящее время они занимают около $5 \%$ от всей суши $[3,4]$.

Урбанофлора - особый вид флоры, существующий в условиях урбанизированной территории. Она, с одной стороны, основополагающая составляющая экосистемы города, с другой - обеспечивает сохранение флористического континуума на антропогенно преобразованных территориях. Формирование урбанофлоры представляет собой процесс антропогенной трансформации растительного покрова, его синантропизации.

Первые работы по урбанофлористике появились уже в XVII в., например, первый перечень видов растений окрестностей Братиславы был опубликован еще в 1583 г. [5]. Исследование урбанофлор крупное направление в ботанической науке. К настоящему времени достаточно подробно изучены флоры многих городов Российской Федерации. Нам известно около 150 работ, посвященных анализу фиторазнообразия 126 городов РФ. Среди них 12 монографий и 40 диссертационных работ. Большая часть таких исследований (около 80\%) проведена в Европейской части России. Исследованиями охвачены города-миллионеры, крупные и малые города.

При общем высоком уровне ботанических исследований на Урале, флора урбанизированных территорий практически не являлась предметом специальных исследований. Лишь в отдельных работах можно найти данные по этому вопросу. Так, в работах Е.А. Шуровой $[6,7]$ есть данные по флоре Шарташского лесопарка г. Екатеринбурга, по таксономическому разнообразию адвентивных растений (приводится 130 видов), а в работах И.И. Шиловой $[8,9]$ имеется информация о растениях, произрастающих на заводских территориях и полигонах ТБО Екатеринбурга. Отдельные работы по флоре урбанизированных территорий в последнее время выполнены на Южном Урале и посвящены урбанофлоре Оренбурга [10] и Орска [11].

В настоящей работе впервые дается развернутая характеристика таксономической структуры флоры урбанизированных территорий Среднего Урала в пределах Свердловской области.

Материаль и методы. Свердловская область является одним из наиболее урбанизированных регионов в стране - доля городского населения на 2013 г. составила около $84 \%$ (в среднем по России $73 \%$ ). В качестве объекта исследований нами выбрана южная часть Свердловской области, которая отличается высокой концентрацией населения, промышленного и сельскохозяйственного производства, здесь хорошо развита транспортная сеть, представленная автомобильными и железными дорогами и наиболее высокий уровень антропогенной деградации растительности, достигающий $70 \%$ [12]. Соответственно, здесь наиболее активно протекают процессы формирования урбанофлор. И на наш взгляд, именно эти районы представляют наибольший интерес для изучения особенностей структуры и закономерностей формирования урбанофлоры Среднего Урала.
Исследования состава урбанофлоры проведены в городах Екатеринбурге, Каменске-Уральском и Красноуфимске в период 2002-2013 гг. Екатеринбург (в 1924-1991 гг. Свердловск) - областной центр Свердловской области - расположен на восточном склоне Уральских гор вдоль реки Исети, в южно-таежной зоне Урала. Каменск-Уральский находится в юго-восточной части Свердловской области в месте слияния двух рек - Исети и Каменки, в подзоне северной лесостепи, а Красноуфимск - в юго-западной части Свердловской области, в долине реки Уфы, в подзоне северной лесостепи.

Городская флора взята в границах зоны городской застройки с прилегающими районами лесопарков или зеленых зон городов. Сетью маршрутов были охвачены все основные типы местообитаний (лесопарки, водоемы, обочины железных и шоссейных дорог, территории промышленных предприятий, полигонов твердых бытовых отходов, искусственные зеленые насаждения, газоны, дворовые территории и т. д.). По материалам полевых исследований, которые были дополнены материалами Гербариев Института экологии растений и животных УрO PAH (SVER) и Курганского государственного университета составлен сводный список урбанофлоры Среднего Урала. В состав урбанофлоры нами включено все множество растений, спонтанно (без целенаправленного участия человека) произрастающих в пределах административных границ населенного пункта. Собран гербарий, насчитывающий около 3000 листов, который хранится на кафедре ботаники Уральского федерального университета имени первого Президента России Б.Н. Ельцина (UFU).

Анализ урбанофлоры проводился по общепринятым в сравнительной флористике методикам $[13,14]$. Учтены методические рекомендации по изучению урбанофлоры, разработанные в последние десятилетия $[5,15$, 16 и др.]. Для оценки сходства видового состава урбанофлор изученных городов использован коэффициент Чекановского-Съеренсена и мера включения Симпсона [17]. Взаимосвязь между числом видов и площадью флоры оценивали с помощью непараметрического коэффициента корреляции Спирмена (r).

Результаты и их обсуждение. Флора урбанизированных территорий Среднего Урала насчитывает, согласно нашим данным, 1093 вида сосудистых растений 492 родов 119 семейств. Наибольшим видовым богатством отличается флора Екатеринбурга, на втором месте по этому показателю стоит флора КаменскаУральского, а на третьем - Красноуфимска (табл. 1). Весьма показательным в этом плане является и тот факт, что на рассматриваемых нами урбанизированных территориях общей площадью около 682 км² $^{2}(0,004 \%$ от площади Свердловской области) представлено более половины (64\%) региональной флоры: 1093 и 1591 видов соответственно.

Подобные данные получены исследователями урбанофлор и в других регионах. Например, в составе флоры 6 урбанизированных территорий Карелии, общей площадью около 197 км² $^{2}(0,001 \%$ от площади республики) насчитывается 753 вида, что составляет около $60 \%$ региональной флоры [18], а для локальных урбанофлор этот показатель составляет 30-48\% [18, 19]. Количество видов в 7 городах Мордовии (общая пло-

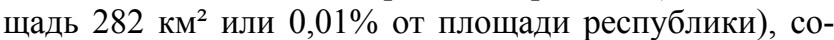


ставляет 74\% состава растений республики, при этом на территории г. Саранска встречается $65 \%$ видов региональной флоры, а в малых городах в среднем $-41 \%$ [20].

Таблица 1 - Таксономический состав урбанофлор Среднего Урала

\begin{tabular}{|l|c|c|c|c|}
\hline \multirow{2}{*}{ Характеристика } & \multicolumn{4}{|c|}{ Урбанофлора } \\
\cline { 2 - 5 } & $\begin{array}{c}\text { Сред- } \\
\text { Уего } \\
\text { Урала }\end{array}$ & $\begin{array}{c}\text { Екате- } \\
\text { ринбург- } \\
\text { ская }\end{array}$ & $\begin{array}{c}\text { Ка- } \\
\text { мен- } \\
\text { ская }\end{array}$ & $\begin{array}{c}\text { Красно- } \\
\text { уфим- } \\
\text { ская }\end{array}$ \\
\hline Площадь, км \\
Численность \\
$\begin{array}{l}\text { населения, тыс. } \\
\text { чел. }\end{array}$ & 1143 & 142 & 48 \\
\hline Число семейств & 119 & 115 & 104 & 100 \\
\hline Число родов & 492 & 464 & 410 & 362 \\
\hline Число видов & 1093 & 971 & 753 & 607 \\
\hline
\end{tabular}

Если сравнить эти материалы с природными флорами, то мы обнаруживаем сходные соотношения. Так, на примере Вологодской области было показано, что локальные флоры насчитывают в среднем 54\% видов от общего их числа во флоре Вологодской области [21]. Н.И. Науменко [22] на примере Южного Зауралья показал, что число видов в локальных флорах варьирует в пределах от 468 до 805 видов, что составляет от $37 \%$ до 64\% видов, зарегистрированных в этом регионе.

Как и в случае естественных флор, видовое богатство которых зависит от площади [23, 24, 25], видовое богатство урбанофлор также тесно связано с площадью [26, 27, 28, 29]. Согласно нашим данным (см. таблицу 1) и многочисленным литературным данным, которые обобщены в работе С.А. Сенатора и др. [28], диапазон видового богатства во флоре городов-миллионеров составляет от 900 до 1600 видов, тогда как флора крупных и больших городов насчитывает в своем составе 800 видов, средних и малых - 500 видов. Соответственно четко прослеживается общая закономерность таксономическое разнообразие урбанофлоры возрастает по мере увеличения площади города и численности населения. Нами выявлена высокая положительная корреляция видового богатства урбанофлор Среднего Урала с их площадью $(\mathrm{r}=0,98)$. Следует также отметить, что не только видовое богатство повышается с увеличением площади урбанофлоры, но и количество в ее составе надвидовых таксонов. Так, в самой маленькой по площади Красноуфимской урбанофлоре насчитывается 362 рода, 99 семейств, а в самой территориально крупной Екатеринбургской урбанофлоре 465 родов и 115 семейств. В средней по размерам Каменской урбанофлоре представлены растения 409 родов, 104 семейств (см. табл. 1).

Видовое богатство растений на урбанизированных территориях Среднего Урала не только не уступает сопоставимым по площади природным локальным флорам, но и превосходит их. Так, видовое богатство Екатеринбургской урбанофлоры в 2 раза выше сопоставимой с ней по площади флорой Национального парка «Припышминские боры» и Висимского биосферного заповедника. Такая же ситуация и в случае Каменской урбанофлоры - она превосходит по этому показателю близкую по площади флору природного парка «Оленьи ручьи» (табл. 2). Это подтверждает неоднократно от- меченный многими исследователями факт повышенного флористического богатства урбанофлоры $[4,5]$.

Таблица 2 - Видовое богатство флор ООПТ Среднего Урала

\begin{tabular}{|l|c|c|}
\hline \multicolumn{1}{|c|}{ Флора } & $\begin{array}{c}\text { Площадь, } \\
\text { км }^{2}\end{array}$ & $\begin{array}{c}\text { Общее число } \\
\text { видов }\end{array}$ \\
\hline $\begin{array}{l}\text { Национальный парк «При- } \\
\text { Пышминские боры» [30] }\end{array}$ & 487 & 630 \\
\hline $\begin{array}{l}\text { Биосферный заповедник } \\
\text { «исимский» [31] }\end{array}$ & 461 & 437 \\
\hline $\begin{array}{l}\text { Природный парк «Оленьи } \\
\text { ручьи» [32] }\end{array}$ & 120 & 670 \\
\hline
\end{tabular}

Несмотря на существенные различия по видовому богатству, локальные урбанофлоры Среднего Урала обладают высоким видовым сходством: коэффициент Чекановского-Съеренсена варьирует от 0,72 до 0,78 , а Жаккара - от 0,56 до 0,64. Высокое сходство урбанофлор фиксируется и при оценке мер включения: максимальное значение $(0,93)$ регистрируется для Красноуфимской и Екатеринбургской урбанофлор. Для Каменской и Екатеринбургской, а также Красноуфимской и Каменской урбанофлор это показатель одинаков и равен 0,88 .

Во флоре урбанизированных территорий представлены все группы сосудистых растений, но, как и в естественных флорах умеренных широт, преобладают покрытосеменные $(96,4 \%)$ двудольные $(76,4 \%)$ растения (таблица 3). В то же время вклад представителей различных отделов региональной флоры в формирование урбанофлоры существенно различается (см. табл. 3). Более полно в составе флоры урбанизированных территорий представлен отдел Pinophyta: $89 \%$ голосеменных растений региональной флоры вошли и в состав флоры урбанизированных территорий. Среди споровых растений более полно представлены отделы Equisetophyta и Polypodiophyta, из которых в состав урбанофлоры вошло 70\% и $60 \%$ видов соответственно. Крайне бедно представлен отдел Lycopodiophyta только $27 \%$ видов плаунов отмечены в составе урбанофлоры. Относительная доля споровых растений во флоре урбанизированных территорий Среднего Урала такая же $(2,8 \%)$, что и во флоре Челябинской $(2,6 \%)$ и Курганской $(2,9 \%)$ областей, но несколько ниже, чем в региональной флоре Свердловской области $(3,5 \%)$ и Пермского края - 3,4\% [22; 33; 34]. Сокращение разнообразия споровых растений на урбанизированных территориях рассматривается многими авторами $[4,5,16$, 20] в качестве характерной черты урбанофлор.

Почти две трети представителей Цветковых растений региональной флоры (67\%) вошли в состав флоры урбанизированных территорий. При этом двудольных $72 \%$, а однодольных - меньше 59\%. Таким образом, в урбанофлоре по сравнению с региональной флорой наблюдается повышение доли двудольных растений (76,2\% против 72,5\%) и, соответственно, уменьшение участия однодольных (20,3\% против 23,4\%). Соотношение двудольных и однодольных во флоре урбанизированных территорий составляет 3,8 , тогда как в региональных флорах Свердловской области, Южного Зауралья, Пермского края, Челябинской области отношение двудольные/однодольные варьирует от 3,1 до 3,2 $[22,33,34]$. Таким образом, для флоры урбанизирован- 
ных территорий характерно снижение относительной значимости однодольных и увеличение доли двудольных растений $[4,5,16,20]$.

Таблица 3 - Состав крупных таксономических групп в региональной флоре Свердловской области (I) и флоре урбанизированных территорий Среднего Урала (II), абс. $/ \%$

\begin{tabular}{|l|c|c|}
\hline \multicolumn{1}{|c|}{ Отдел, класс } & I & II \\
\hline Отд. Lycopodiophyta & $11 / 0,7$ & $3 / 0,3$ \\
\hline Отд. Equisetophyta & $10 / 0,6$ & $7 / 0,6$ \\
\hline Отд. Polypodiophyta & $35 / 2,2$ & $21 / 1,9$ \\
\hline Отд. Pinophyta & $9 / 0,6$ & $8 / 0,7$ \\
\hline Отд. Magnoliophyta & $1526 / 95,9$ & $1052 / 96,4$ \\
\hline в том числе: & & \\
\hline \multicolumn{1}{|c|}{ кл. Liliopsida } & $372 / 23,4$ & $221 / 20,3$ \\
\hline \multicolumn{1}{|c|}{ кл. Magnoliopsida } & $1154 / 72,5$ & $831 / 76,2$ \\
\hline Всего & $1591 / 100,0$ & $1091 / 100,0$ \\
\hline
\end{tabular}

Возглавляют семейственно-видовой спектр урбанофлоры семейства Asteraceae, Poaceae, Rosaceae, Fabaceae, Brassicaceae, Caryophyllaceae, Cyperaceae, Ranunculaceae, Lamiaceae, Scrophulariaceae. В общей сложности они включают 56\% флоры урбанизированных территорий. Их состав полностью совпадает с составом ведущих семейств флоры Свердловской области (табл. 4) и типичен для бореальных флор Голарктического флористического царства [13]. Регистрируются лишь изменения в относительной значимости отдельных семейств и, соответственно, в их ранге. Так, во флоре урбанизированных территорий Среднего Урала семейство Cурегаceae, занимает 7-е место, а в бореальных флорах оно располагается на 3-4-м месте. Наоборот, в урбанофлоре повышается значимость видов семейства Fabaceae. Если в бореальных оно располагается на 6-9-ом местах [13, 33, 34], то во флоре урбанизированных территорий его ранг повышается, и оно располагается на 4-м месте.

Таблица 4 - Головная часть семейственно-видового спектра флоры Свердловской области (I) и флоре урбанизированных территорий Среднего Урала (II)

\begin{tabular}{|c|c|c|c|c|c|c|}
\hline \multirow{3}{*}{ Семейство } & \multicolumn{3}{|c|}{$\mathrm{I}$} & \multicolumn{3}{|c|}{ II } \\
\hline & \multirow{2}{*}{ Рані } & \multicolumn{2}{|c|}{ Кол-во } & \multirow{2}{*}{ Ранг } & \multicolumn{2}{|c|}{ Кол-во } \\
\hline & & aбc. & $\%$ & & абс. & $\%$ \\
\hline Asteraceae & 1 & 226 & 14,2 & 1 & 143 & 13,1 \\
\hline Poaceae & 2 & 150 & 9,4 & 2 & 96 & 8,8 \\
\hline Rosaceae & 3 & 108 & 6,8 & 3 & 86 & 7,9 \\
\hline Cyperaceae & 4 & 103 & 6,5 & 7 & 43 & 3,9 \\
\hline Caryophyllaceae & 5 & 73 & 4,6 & $5-6$ & 46 & 4,2 \\
\hline Fabaceae & 6 & 71 & 4,5 & 4 & 48 & 4,4 \\
\hline Brassicaceae & 7 & 66 & 4,1 & $5-6$ & 46 & 4,2 \\
\hline Ranunculaceae & 8 & 62 & 3,9 & 8 & 36 & 3,3 \\
\hline Scrophulariaceae & 9 & 59 & 3,7 & 10 & 32 & 2,9 \\
\hline Lamiaceae & 10 & 44 & 2,8 & 9 & 34 & 3,1 \\
\hline $\begin{array}{l}\text { Всего в ведущих } \\
\text { семействах }\end{array}$ & - & 962 & 60,5 & - & 610,0 & 55,8 \\
\hline
\end{tabular}

Около трети семейств - 37 семейств или $31 \%$ являются одновидовыми, что существенно выше, чем в региональных флорах: около 20\% [22, 33-35]. Большая часть семейств - 47 семейств $(39,5 \%)$ представлена $2-5$ видами, а остальные - 29,4\% - более чем 6 видами. В среднем видовая насыщенность семейства во флоре урбанизированных территорий Среднего Урала составляет 9,2 и в целом соответствует таковой для урбанофлоры Карелии - 7,5 [16], Мордовии - 9,8 [20]. Однако она заметно ниже, чем в региональных флорах: Южное Зауралье - 11,3 [22], Челябинская область - 13,5 [33], Пермский край - 15,4 [34], Удмуртия - 14,7 [35].

Самыми крупными родами флоры урбанизированных территорий Среднего Урала в порядке убывания являются Carex, Potentilla, Alchemilla, Artemisia, Salix, Rumex, Viola, Galium, Poa, Ranunculus и, в целом, их состав традиционен для бореальных флор [21, 22, 33 35 и др.]. Родовой спектр урбанофлоры отличает повышенное участие в нем родов Atriplex и Chenopodium и крайне ограниченная представленность родов Hieracium и Taraxacum (табл. 5).

Таблица 5 - Ведущие по видовой насыщенности роды во флоре Свердловской области (I) и урбанизированных территорий Среднего Урала (II)

\begin{tabular}{|l|c|c|c|c|}
\hline \multirow{2}{*}{\multicolumn{1}{|c|}{ Род }} & \multicolumn{2}{|c|}{ І } & \multicolumn{2}{c|}{ ІІ } \\
\cline { 2 - 5 } & Ранг & $\begin{array}{c}\text { Число } \\
\text { видов }\end{array}$ & Ранг & $\begin{array}{c}\text { Число } \\
\text { видов }\end{array}$ \\
\hline Carex & 1 & 77 & 1 & 32 \\
\hline Hieracium & 2 & 46 & - & 2 \\
\hline Alchemilla & 3 & 37 & $3-4$ & 19 \\
\hline Potentilla & 4 & 28 & 2 & 20 \\
\hline Salix & 5 & 27 & 5 & 15 \\
\hline Artemisia & 6 & 23 & $3-4$ & 19 \\
\hline Poa & $7-8$ & 20 & $9-10$ & 12 \\
\hline Ranunculus & $7-8$ & 20 & $9-10$ & 12 \\
\hline Potamogeton & 9 & 17 & 11 & 11 \\
\hline Taraxacum & $10-12$ & 16 & - & 3 \\
\hline Viola & $10-12$ & 16 & $6-8$ & 13 \\
\hline Galium & $10-12$ & 16 & $6-8$ & 13 \\
\hline Rumex & $13-14$ & 15 & $6-8$ & 13 \\
\hline Veronica & - & 14 & $13-16$ & 9 \\
\hline Campanula & - & 11 & 12 & 10 \\
\hline Atriplex & - & 9 & $13-16$ & 9 \\
\hline Chenopodium & - & 12 & $13-16$ & 9 \\
\hline
\end{tabular}

Подавляющая часть родов во флоре урбанизированных территорий $(295$, или $60,2 \%)$ - одновидовые. В среднем видовая насыщенность рода, отражающая соотношение автохтонных и аллохтонных тенденций в развитии флоры [13], составляет 2,2. Это соответствует видовой насыщенности рода $(2,1)$ для флор урбанизированных территорий Мордовии и Карелии [16, 20], но ниже чем в региональных флорах Южного Зауралья, Челябинской области, Пермского Края и Удмуртии: 2,7-3,3 [22, 33-35].

Bblвoдbl. Подводя итог всему выше изложенному, мы находим возможным, охарактеризовать с позиций таксономического и эколого-биоморфологического состава флору урбанизированных территорий Среднего Урала следующим образом.

1. Урбанофлору Среднего Урала отличает повышенный уровень видового богатства. При этом, как и в случае естественных флор, таксономическое разнообразие урбанофлоры возрастает по мере увеличения площади города. В частности, максимальное число видов нами отмечено в составе урбанофлоры областного центра города-миллионера Екатеринбурга, который отличают наибольшая площадь среди сравниваемых городов. Уровень видового богатства урбанофлоры меньших по площади городов существенно ниже. 
2. Таксономическая структура урбанофлоры отражает особенности региональной флоры, в силу чего, ей присущи соответствующие региональные и зональные черты. В то же время урбанофлора имеет некоторые характерные особенности, которые можно считать общими для флор урбанизированных территорий. В частности, в таксономической структуре урбанофлоры, в сравнении с региональными флорами, снижается участие споровых растений, за счет крайне бедной представленности плауновидных. Среди цветковых растений снижается доля однодольных и, наоборот, повышается - двудольных.

3. В составе ведущих семейств урбанофлоры понижает свой ранг семейство Cyperaceae, характерное для бореальных флор, одновременно повышается значимость семейства Fabaceae. В родовом спектре повышается роль термофильных родов Atriplex и Chenopodium, при крайне ограниченной представленности многовидовых в региональной флоре родов Hieracium и Taraxacum.

\section{СПИСОК ЛИТЕРАТУРЫ:}

1. Мамин Р.Г. Урбанизация и охрана окружающей среды в Российской Федерации / РЭФИА. М., 1995. Ч. 1.80 с.; Ч. 2.139 c.

2. Новая иллюстрированная энциклопедия. М.: Научное издательство «Большая российская энциклопедия», 2002. Т. 19. $256 \mathrm{c.}$

3. Лаппо Г.М. География городов. М.: Гуманитарный издательский центр ВЛАДОС, 1997. 480 с.

4. Березуцкий М.А., Панин А.В. Флора городов: структура и тенденции антропогенной динамики // Ботан. журн. 2007. Т. 92. № 10. С. 1481-1489.

5. Ильминских Н.Г. Флорогенез в условиях урбанизированной среды. Екатеринбург: Изд-во УрО РАН, 2014. $470 \mathrm{c}$.

6. Шурова Е.А. Флора и растительность Шарташского лесопарка // Структура, продуктивность и динамика растительного покрова. Свердловск, 1990. С. 111-123.

7. Шурова Е.А. Адвентивная флора г. Свердловска и его окрестностей // Рациональное использование и охрана растительного мира Урала. Свердловск: УрО AH CCCP, 1991. C. 128-133.

8. Шилова И.И. Естественная растительность заводских территорий индустриального центра // Растения и промышленная среда: Сб. науч. трудов. Свердловск: УрГУ, 1989. С. 44-56.

9. Шилова И.И. Естественная растительность свалок и полигонов твердых бытовых и промышленных отходов в условиях крупного промышленного города // Естественная растительность промышленных и урбанизированных территорий Урала. Свердловск: УрО АН СССР, 1990. Стр. 41-57.

10. Макарова Н.Н. Флора и растительность урбанизированной территории степной зоны Южного Урала (на примере г. Оренбурга): автореф. дис. ... канд. биол. наук. Оренбург, 2000. 21 с.

11. Лупова И.В. Современное состояние растительного покрова урбанизированных территорий степной зоны (на примере города Орска): автореф. дис. ... канд. биол. наук. Оренбург, 2006. 21 с.

12. Горчаковский П.Л., Никонова Н.Н., Фамелис Т.В. Фитоэкологическая карта Свердловской области: (Методика составления и система оценки антропогенных воздействий) // Пробл. регион. экологии (Екатеринбург). 1995. Сигнал. вып. С. 38-47.
13. Толмачев А.И. Введение в географию растений. Л.: Изд-во Ленингр. ун-та, 1974. 244 с.

14. Юрцев Б.А., Камелин Р.В. Основные понятия и термины флористики: учеб. пособ. по спецкурсу. Пермь, 1991. 80 c.

15. Григорьевская А.Я. Флора города Воронежа. Воронеж, 2000. $200 \mathrm{c}$.

16. Антипина Г.С. Урбанофлора Карелии. Петрозаводск, 2002. $200 \mathrm{c}$.

17. Шмидт В.М. Математические методы в ботанике. Л.: Изд-во ЛГУ, 1984. 156 с.

18. Антипина Г.С. Урбанофлора как компонент экосистем городов таежной зоны (на примере Карелии) // Экология. 2003. № 4. С. 243-247.

19. Тимофеева В.В. Флора малых городов южной Карелии (состав, анализ): автореф. дис. ... канд. биол. наук // Санкт-Петербург, 2006. 16 с.

20. Письмаркина Е.В. Флора городов республики Мордовия: автореф. ... дис. канд. биол. наук. Саранск, 2006. 24 c.

21. Сергиенко В.Г. Пространственная дифференциация флоры центральной части Европейского Севера. ФГУ «СПбНИИЛХ» СПб., 2011. 116 с.

22. Науменко Н.И. Флора и растительность Южного Зауралья. Курган: Изд-во Курганского гос. ун-та, 2008. $512 \mathrm{c}$.

23. Малышев Л.И. Зависимость флористического богатства от внешних условий и исторических факторов // Ботан. журн. 1969. Т. 54, № 8. С. 1137-1147.

24. Малышев Л.И. Влияние экологических факторов на видовое богатство флоры России // Бот. иссл. в Азиатской России. Матер. XI съезда Русск. бот. общ-ва. Барнаул, 2003. Т. 1. С. 365-367.

25. Толмачев А.И. Богатство флор как объект сравнительного изучения // Вестн. ЛГУ. Сер. биол. Вып. 2, 1970. № 9. С. 71-83.

26. Тохтарь В.К., Фомина О.В. Особенности формирования урбанофлор в различных природно-климатических и антропогенных условиях: факторный анализ и визуализация данных // Науч. ведомости Белгород. гос. ун-та. Сер. Естеств. науки. 2011. № 9, вып. 15. С. 23-28.

27. Сенатор С.А., Баранова О.Г. Сравнительный анализ флор городов Среднего Поволжья // Вестн. Удм. ун-та. Сер. Биология. Науки о Земле. 2013. Вып. 4. C. $37-46$.

28. Сенатор С.А., Костина Н.В., Саксонов С.В. Зависимость видового разнообразия урбанофлор от ряда факторов // Вестн. Удм. ун-та. Сер. Биология. Науки о Земле. 2013. Вып. 2. С. 23-29.

29. Pyšek P. Alien and native species in Central European urban floras: a quantitative comparison // Journ. of Biogeography. 1998. Vol. 25. P. 155-163.

30. Растения и грибы национального парка «Припышминские боры» / В.А. Мухин, А.С. Третьякова, Д.В. Прядеин и др. Екатеринбург: Изд-во Урал. ун-та, 2003. 204 c.

31. Марина Л.В. Сосудистые растения Висимского заповедника / Под ред. В.Н. Тихомирова (Флора и фауна заповедников СССР: Оператив.-информ. мат. комисс. АН СССР по координации исслед. в заповедниках). М., 1987. Вып. 8. 43 с.

32. Радченко Т.А., Федоров Ю.С. Конспект флоры сосудистых растений «Долины реки Серги» // Экологические исследования на Урале. Екатеринбург: Изд-во Урал. ун-та, 1997. С. 10-27. 
33. Куликов П.В. Конспект флоры Челябинской области (сосудистые растения). Екатеринбург; Миасс: Геотур, 2005. $537 \mathrm{c}$.

34. Биоразнообразие растительного мира Пермского края [Электронный ресурс]: электронное учебное посо- бие для студентов естественнонаучного факультета / Е.М. Шкараба, А.Е. Селиванов, К.А. Карасев. Пермь: ПГГПУ, 2012. 1 электрон. опт. диск (CD-ROM).

35. Баранова О.Г. Местная флора: анализ, конспект, охрана: учеб. пособие. Ижевск, 2002. 199 с.

\section{CHARACTERISTICS OF TAXONOMIC STRUCTURE OF FLORA IN THE MIDDLE URALS URBAN AREAS (SVERDLOVSK REGION)}

(C) 2016

A.S. Tretyakova, candidate of biological sciences, associate professor of the Chair of Botany Ural Federal University named after the first Russian President Boris Yeltsin, Yekaterinburg (Russia)

Abstract. Research in urban floras is a major field of botanical science. By now, flora of many Russian cities has been studied. At the same time the Urals flora of urbanized areas has not practically been the subject of special investigation. This paper is the first to provide a detailed description of the features of the taxonomic structure of the flora of urbanized areas of the Middle Urals within the Sverdlovsk region and to compare it with the parameters of the regional flora of the Sverdlovsk region. Urban floras of 3 cities in the southern part of the Sverdlovsk region have been studied - Yekaterinburg, Krasnoufimsk and Kamensk-Ural, which form a latitudinal catena, covering the Urals region, the mountainous part of the Middle Urals and Trans-Urals. It is shown that the flora of the urbanized areas is characterized by a high level of species richness which increases relative to the area of the city. The taxonomic structure of urban floras, compared with the regional flora, is characterized by a reduced participation of spore plants, due to the extremely poor representation of lycopsids. In the flowering plants the proportion of monocots is reduced and, on the contrary, the proportion of bipartite species is increased. The composition of the leading families of urban floras is typical of the boreal floras of the Holarctic floral kingdom, it is distinguished by the lower rank of the Cyperaceae family and by the rise of the Fabaceae family. Generic spectrum of urban floras is marked by the greater participation of thermophilic genera Atriplex and Chenopodium and very limited representation of boreal genera Hieracium and Taraxacum. Species richness of families and genera in urban floras is markedly lower than in regional boreal flora.

Keywords: urban flora, regional flora, biodiversity, species richness, taxonomic structure, familial-range species, species richness of family, range of the genus, species of the genus richness, the Middle Urals, Sverdlovsk region. 